\title{
"PERLINDUNGAN KONSUMEN TERHADAP PEREDARAN MAKANAN YANG MENGANDUNG PENGAWET BERBAHAYA (STUDI PASAR JUNJUNG BUIH KOTA SINTANG)"
}

\author{
Rini Safarianingsih \\ Fakultas Hukum Universitas Kapuas Sintang \\ Jalan Oevang Oeray 92 Sintang \\ Email : rinisafarie72@ymail.com
}

\begin{abstract}
Packaged food is a food product that is widely circulated and free in the community. Foods that will be circulated for consumption so as not to harm consumers must include adequate, correct, honest and responsible information. So that every business actor in the food sector that is circulated is burdened with responsibility, especially if the food he produces causes losses to consumers. Based on the Decree of the Regent of Sintang Number: 510/156 / KEP-INDAGKOP-C / 2015 dated February 27, 2015, on the Integrated Supervision of Hazardous Materials Abused in Food, a joint team chaired by the Sintang District Health Office held a raid in the Junjung Buih market and the shops in the Sintang Inpres Market. Related to the raid conducted by this integrated team, where the purpose of the raid is in order to anticipate the entry of hazardous materials to the market, such as borax, formalin, dangerous dyes Keywords: Protection, Consumer, food preservatives
\end{abstract}

\section{Abstrak}

Makanan dalam kemasan adalah produk pangan yang beredar luas dan bebas dimasyarakat. Makanan yang akan diedarkan untuk dikonsumsi agar tidak merugikan konsumen harus mencantumkan informasi yang memadai, benar, jujur dan bertanggung jawab. Sehingga setiap pelaku usaha di bidang makanan yang beredar di bebani tanggung jawab terutama apabila makanan yang diproduksinya menyebabkan kerugian pada konsumen. Berdasarkan Surat Keputusan Bupati Sintang Nomor:510/156/KEPINDAGKOP-C/2015 Tanggal 27 Februari 2015, tentang Pengawasan Terpadu Bahan Berbahaya Yang Disalahgunakan Dalam Pangan, tim gabungan yang di ketuai oleh Dinas Kesehatan Kabupaten Sintang menggelar razia di pasar Junjung Buih dan toko-toko yang ada di Pasar Inpres Sintang. Terkait dengan razia yang dilakukan oleh tim terpadu ini, dimana tujuan dari razia ini dalam rangka untuk mengantisipasi masuknya bahan berbahaya ke pasar, seperti borak, formalin, pewarna berbahaya

Kata Kunci : Perlindungan, Konsumen, Pengawet makanan 


\section{Pendahuluan}

Perlindungan konsumen merupakan masalah kepentingan manusia, oleh karenanya menjadi harapan bagi semua bangsa di dunia untuk dapat mewujudkannya. Mewujudkan perlindungan konsumen adalah mewujudkan hubungan berbagai dimensi yang satu sama lain mempunyai keterkaitan dan saling ketergantungan antara konsumen, pengusaha dan pemerintah 22 .

Pelaku usaha sebagai penghasil produk harus menjamin bahwa produk yang dihasilkan cukup aman untuk di konsumsi dan berkualitas. Oleh karena itu, apabila dilain hari muncul keluhan atas kerusakan produk atau keluhan karena mengakibatkan kerugian pada konsumen maka pelaku usaha harus bertanggung jawab penuh atas beban kerugian yang diderita oleh konsumen. Makanan dalam kemasan adalah produk pangan yang beredar luas dan bebas dimasyarakat. Makanan yang akan diedarkan untuk dikonsumsi agar tidak merugikan konsumen harus mencantumkan informasi yang memadai, benar, jujur dan bertanggung jawab. Sehingga setiap pelaku usaha di bidang makanan yang beredar di bebani tanggung jawab terutama apabila makanan yang diproduksinya menyebabkan kerugian pada konsumen.

Dinas Perindustrian, Perdagangan Koperasi, dan Usaha Kecil Menengah

22 Nitisusastro, 2012. Perilaku Konsumen Dalam Perspektif Kewirausahaan, Cetakan Kesatu. Alfabeta, CV. Bandung. hal. 252
(Disperindagkop dan UKM) Kabupaten Sintang menemukan 8 (delapan) Jenis makanan yang beredar di Sintang yang mengandung zat berbahaya, kedelapan jenis ini dinyatakan positif setelah melalui pemeriksaan dari 13 (tiga belas) jenis makanan yang di periksa pada Balai Pengawasan Obat dan Makanan (BPOM). Kepala Disperindagkop dan UKM Kabupaten Sintang, mengatakan bahwa peredaran makanan ini di temukan di tiga warung pada tiga wilayah di Kota Sintang yakni di Baning, Masuka dan pasar Tanjung Puri23.

Berdasarkan Surat Keputusan Bupati Sintang Nomor:510/156/KEP-INDAGKOPC/2015 Tanggal 27 Februari 2015, tentang Pengawasan Terpadu Bahan Berbahaya Yang Disalahgunakan Dalam Pangan, tim gabungan yang di ketuai oleh Dinas Kesehatan Kabupaten Sintang menggelar razia di pasar Junjung Buih dan tokotoko yang ada di Pasar Inpres Sintang. Terkait dengan razia yang dilakukan oleh tim terpadu ini, dimana tujuan dari razia ini dalam rangka untuk mengantisipasi masuknya bahan berbahaya ke pasar, seperti borak, formalin, pewarna berbahaya (Rodhamin B dan Metanil Yellow), pemanis buatan (siklamat) dan klorin (pemutih).24 Masyarakat dalam kehidupan sehari -hari khawatir untuk mengkonsumsi

23 http://suarapemred.co.id/pemerintah-diminta-intensifkan-pengawasan/22

$24 \mathrm{ht} \mathrm{t}$ : / / w w w. mediakapuas r a y a . com/2015/05/07/2694/tim-terpadu-razia-bahanpen-gawet-di-pasar-junjung-buih/05 Juli 2015. 
makanan akibat banyaknya pangan (makanan) yang mengandung bahan - bahan berbahaya, khususnya makanan basah seperti bakso, mie, dan kemudian bertambah luas kekhawatiran itu seperti khawatir dalam hal mengkonsumsi ikan segar dan ikan yang diasinkan, padahal selama ini pangan (makanan) tersebut merupakan sumber protein yang sangat dibutuhkan oleh manusia. Namun, ketika isu formalin menguat maka ketakutan pun melanda masyarakat secara umum, telah diketahui bahwa sejumlah makanan tersebut terdapat kandungan berbahaya yang kemudian diketahui luas sebagai formalin, boraks dan rhodamin. Para ahli mengatakan bahwa formalin adalah sama sekali bukan pengawet pada makanan, dan justru mengandung racun yang berbahaya bagi yang mengkonsumsinya baik dalam jumlah sedikit apalagi banyak. Penggunaan formalin pada makanan yang bila terkontaminasi manusia, secara tidak langsung akan menjadi racun bagi organ tubuh. Hal ini berarti bisa menganggu kesehatan yang ditimbulkan, tidak akan terlihat dalam jangka waktu yang singkat sebagai penyakit yang diakibatkan oleh makanan yang mengandung bakteri patogen. Umumnya gangguan kesehatan karena formalin bersifat menahun (penyakit yang membutuhkan jangka waktu lama untuk masa penyembuhan), kecuali tercemar dalam jumlah banyak. Oleh karena itu, konsumen harus berhati hati dalam menggunakan suatu produk karena dapat berdampak buruk terhadap kesehatan.

\section{Pembahasan}

Penggunaan bahan-bahan tambahan makanan tersebut diatas diatur dalam peraturan tentang bahan tambahan pangan yang boleh maupun yang dilarang oleh departemen kesehatan yaitu Peraturan Mentri Kesehatan Republik Indonesia Nomor 722/Menkes/Per/IX/1988 tentang Bahan Tambahan Makanan, dalam peraturan tersebut BTP digolongkan ke dalam 11 jenis sebagai berikut :25

1. Antioksidan ( Antioksidant).

2. Antikempal ( Anticacking Agent ).

3. Pengatur Keasaman (Acidity Regulator ).

4. Pemanis Buatan (Artificial Sweetener ).

5. Pemutih dan Pematang Tepung ( Flour Treatment Agent ).

6. Pengemulsi, Pemantap dan Pengental ( Emulsifier, Stabilizer, Thickener ).

7. Pengawet ( preservative ).

8. Pengeras ( Firming Agent ).

9. Pewarna ( Colour ).

10. Penyedap rasa dan Aroma, Penguat Rasa ( Flavour ; Flavour enhancer ). 11. Sekuestran (sequestrant) / pengikat $25 \quad$ Fardiaz, Dedi. Buku panduan Pengolahan pangan yang baik Bagi Industri Rumah Tangga 
logam.

Sedangkan bahan tambahan pangan yang dilarang digunakan menurut Permenkes RI No. 722/Menkes/Per/IX/1988 dan No 1168/Menkes/ Per/X/1999 tentang Bahan Tambahan Makanan sebagai berikut:

1. Natrium Tetraborat ( Borax)

2. Formalin (Formaldehyde)

3. Minyak Nabati yang di Brominasi/ Brominated vegetable oil.

4. Kloramfenikol ( Chlorampenicol )

5. Kalium Klorat ( Potassium Chlorate )

6. Diethil pirokarbonat (Diethyl Pyrocarbonate, DEPC)

7. Nitrofurazon (Nitrofurazon)

8. P-Penetilkarbamida PPenethylcarbamide, dulcin,4-ethoxy phenil uea)

9. Asam Salisilat dan Garamnya ( salicylic acid and its salt)

Menurut Permenkes No 1168/Menkes/ Per/X/1999, ada tambahan bahan yang tidak diperbolehkan untuk makanan yaitu: Rhodamin B (pewarna merah), Methanyl Yellow (pewarna kuning), Dulsin (pemanis sintesis) dan Potassium Bromat (pengeras).

Penggunaan bahan- bahan pengawet, pemanis dan penyedap makanan atau yang ditambahkan terhadap makanan dan minuman sebagaimana pasal 3 peraturan kepala BPOM Nomor 36 Tahun 2013 Tentang Batas Maksimum Penggunaan Bahan Tambahan Pangan Pengawet, Pasal 3 menyatakan;

“ Jenis BTP Pengawet yang diizinkan digunakan dalam pangan terdiri atas: 1.Asam sorbat dan garamnya ( Sorbic acid and its salts );2.Asam benzoat dan garamnya ( Benzoic acid and its salts);3.Etil para-hidroksibenzoat ( Ethyl para-hydroxybenzoate );4.Metil parahidroksibenzoat ( Methyl parahydroxybenzoate );5.Sulfit ( Sulphites );6. Nisin ( Nisin ); 7.Nitrit ( Nitrites ); 8.Nitrat ( Nitrates ); 9.Asam propionat dan garamnya (Propionic acid and its salts ); dan 10.Lisozim hidroklorida (Lysozyme hydrochloride )"

Selanjutnya dinyatakan dalam Pasal 4, Batas Maksimum penggunaan BTP Pengawet sebagaimana dimaksud dalam Pasal 3 untuk setiap Kategori Pangan sebagaimana tercantum dalam Lampiran I yang merupakan bagian tidak terpisahkan dari Peraturan ini. Kemudian dalam pasal 5 ayat (1) memberikan syarat bahwa :

“ (1) penggunaan BTP Pengawet dibuktikan dengan sertifikat analisis kuantitatif; (2) Dikecualikan dari ketentuan sebagaimana dimaksud pada ayat (1), untuk penggunaan BTP pada Kategori Pangan 
dengan Batas Maksimum CPPB dibuktikan dengan sertifikat analisis kualitatif;(3) Jenis BTP Pengawet yang tidak dapat dianalisis, Batas Maksimum dihitung berdasarkan penambahan BTP Pengawet yang digunakan dalam pangan".

Sanksi dalam ketentuan peraturan badan pengawas obat dan makanan ini sebagaimana pasal 10 menyatakan :

"Pelanggaran terhadap ketentuan dalam

Peraturan ini dapat dikenai sanksi

administratif berupa: a.peringatan secara

tertulis; b.larangan mengedarkan untuk sementara waktu dan/atau perintah untuk penarikan kembali dari peredaran; c.perintah pemusnahan, jika terbukti tidak memenuhi persyaratan keamanan atau mutu; dan/atau d.pencabutan izin edar”. Dalam Undang-Undang No. 8 Tahun 1999

Tentang Perlindungan Konsumen pada hakikatnya dilandasi oleh pemikiran bahwa konsumen sering sekali berada di posisi yang tidak menguntungkan apabila dihadapkan dengan produsen atau pelaku usaha yang mempunyai orientasi dan kekuasaan yang tidak seimbang dengan konsumen. Perlindungan atas kepentingan konsumen tersebut diperlukan mengingat kenyataan bahwa pada umumnya konsumen selalu berada di pihak yang dirugikan, akibat perbuatan curang produsen atau pelaku usaha yang menimbulkan kerugian bagi konsumen seperti makanan atau minuman yang tidak memenuhi standar mutu dan gizi pangan, biskuit beracun, makanan yang kadaluarsa dan makanan yang diharamkan, serta ditemukannya bahan-bahan berbahaya kedalam makanan seperti, pengawet, pewarna, pengenyal, pemutih, pemanis, dan semacamnya.26 Ada 4 (empat) alasan pokok mengapa konsumen perlu dilindungi, yaitu sebagai berikut :

"1. Melindungi konsumen sama artinya dengan melindungi seluruh bangsa sebagaimana diamanatkan oleh tujuan pembangunan nasional menurut UUD 1945;2. Melindungi konsumen perlu untuk menghindarkan konsumen dari dampak negative penggunaan teknologi;3. Melindungi konsumen perlu untuk melahirkan manusia-manusia yang sehat rohani dan jasmani sebagai pelaku-pelaku pembangunan, yang berarti juga untuk menjaga kesinambungan pembangunan nasional;4. Melindungi konsumen perlu untuk menjamin sumber dana pembangunan yang bersumber dari masyarakat konsumen. Dalam pandangan ini secara tegas dinyatakan bahwa upaya untuk melakukan perlindungan konsumen disebabkan adanya tindakan-tindakan atau perbuatan para pelaku usaha dalam menjalankan aktifitas bisnisnya yang tidak jujur sehingga dapat merugikan konsumen, praktek-praktek yang dijalankan salah satunya mengunakan

26 2Janus Sidabalok, Hukum Perlindungan Konsumen di Indonesia, (Bandung : PT. Citra Aditya Bakti, 2010), hal. 06. 
bahan kimia sebagai bahan campuran dalam pengawetan makanan, misalanya formalin, boraks.”

Hak konsumen di Indonesia sebagaimana tertuang dalam Pasal 4 Undang-Undang No. 8 Tahun 1999 tentang Perlindungan Konsumen adalah sebagai berikut:

1) Hak atas kenyamanan, keamanan, dan keselamatan dalam mengkonsumsi barang atau jasa.

2) Hak untuk memilih barang atau jasa serta mendapatkan barang atau jasa tersebut sesuai dengan nilai tukar dan kondisi serta jaminan yang dijanjikan.

3) Hak atas informasi yang benar, jelas, dan jujur mengenai kondisi dan jaminan barang atau jasa.

4) Hak untuk didengar pendapat dan keluhannya atas barang atau jasa yang digunakan.

5) Hak untuk mendapatkan advokasi, perlindungan, dan upaya penyelesaian sengketa perlindungan konsumen secara patut.

6) Hak untuk mendapat pembinaan dan pendidikan konsumen.

7) Hak untuk diperlakukan atau dilayani secara benar dan jujur serta tidak diskriminatif.

8) Hak untuk mendapatkan kompensasi, ganti rugi atau penggantian, apabila barang atau jasa yang diterima tidak sesuai dengan perjanjian atau tidak sebagaimana mestinya.

9) Hak-hak yang diatur dalam ketentuan peraturan perundang-undangan lainnya.

Perlindungan dan Penegakan Hukum Terhadap Konsumen Dari Zat Berbahaya Pada Pangan (Makanan) Sebelum adanya undangundang tentang Perlindungan Konsumen, sangat sulit bagi para konsumen untuk menuntut kerugiannya. Dalam hal terjadinya kerugian bagi konsumen, produsen atau pelaku usaha bertanggungjawab untuk menanggung segala kerugian yang diderita oleh konsumen hanyalah berdasarkan perbuatan melawan hukum. Hal ini dapat dilihat pada Pasal 1365 KUHPerdata yang menentukan bahwa "tiap-tiap perbuatan melanggar hukum, yang membawa kerugian kepada orang lain, mewajibkan orang yang karena salahnya menertibkan kerugian itu, mengganti kerugian tersebut. Terkait dengan penegakan hukum terhadap konsumen dari zat berbahaya pada pangan (makanan) dimana Pemerintah telah mengeluarkan peraturan perundang-undangan maupun peraturan yang berkaitan dengan keamanan baik ditingkat produksi maupun ditingkat distribusi.

Pasar Junjung Buih terletak di jalan Pangeran Kuning Kecamatan Sintang, memiliki jumlah penduduk 27.938 jiwa terdiri dari 14.440 jiwa laki-laki dan 13.498 jiwa perempuan, lokasi pasar Junjung Buih dahulu bernama Pasar Inpres terdapat 52 blok kios yang menjual bermacam- 
macam kebutuhan masyarakat terutama bahanbahan makanan basah seperti sayuran, ikan, daging serta kue-kue jajanan pasar terdapat pula penjual jamu dan bahkan ada pula penjual asesoris dan pakaian, setelah renovasi pasar pada tahun 2014 Pasar Inpres ini diganti dengan nama Pasar Junjung Buih, bangunan pasar permanen tidak lagi membuat blok atau kios-kios didalam bangunan sehingga tidak terlihat sumpek dan memudahkan masyarakat berbelanja.

Areal di sekitar Pasar Junjung Buih terdapat beberapa rumah-rumah toko yang menjual berbagai aneka keperluan masyarakat, terdapat pula pasar buah dan gedung kantor bank, terminal, tempat ibadah, rumah sakit umum dan pos keamanan. Kompleks Pasar Junjung Buih selalui ramai dengan transaksi jual beli yang cukup tinggi setiap harinya apalagi pada hari libur kerja atau menjelang hari raya sehingga perputaran ekonomi terlihat cukup baik dalam menunjang pendapatan penjual di sekitar lokasi pasar.

\section{A. Upaya Mengatasi Beredarnya Makanan} Yang Mengandung Pengawet

\section{Berbahaya}

Berdasarkan hasil pencarian penulis melalui website Badan Pengawasan Obat dan Makanan (BPOM) yang diakses pada tanggal 02 April 2016 didapat informasi bahwa lingkup wilayah pengawasan BPOM untuk Kalimantan Barat terdapat di Ibukota Provinsi yaitu Pontianak.27 Melalui hubungan telepon pada tanggal 15 April 2016 kepada Dra. Yanuarti Apt. Selaku Kepala Bidang Sertifikasi dan Layanan Informasi Konsumen didapatkan hasil wawancara sebagai berikut :

Cara yang aman dan mudah terhindar dari makanan dan minuman yang mengandung bahanbahan berbahaya seperti pewarna, pemanis, perasa, pengawet, penguat rasa, pengenyal, pemutih, dan lain sebagainya adalah dengan belajar bagaimana mengenali dan mengidentifikasi tanda atau ciri-ciri makanan yang tidak layak konsumsi. Lalu di samping itu kita juga berupaya menghindari membeli dan mengkonsumsi makanan dan minuman yang dijual di tempat-tempat yang tidak meyakinkan. Biasakan juga untuk membuat makanan dan minuman sendiri untuk kebutuhan sehari-hari dengan bahan-bahan pangan yang aman. Bukan hanya untuk kebaikan diri kita saja, namun juga orang lain yang ada di sekitar kita. Selain itu jika mencurigai adanya makanan yang mengandung pengawet berbahaya atau sejenisnya konsumen dapat melaporkan pada dinas pendidikan dan dinas kesehatan Kabupaten Sintang untuk dilakukan sampling dan tindak lanjut.

Sementara itu menurut keterangan balaipom bahwa Balai Besar POM di Pontianak tidak memiliki cabang atau unitnya di Kabupaten/Kota,

27 http://www.pom.go.id/new/index.php/view/lingkup 
tetapi wilayah pengawasannya sampai ke

Kabupaten/ Kota. Mengenai Tugas Utama BPOM

Berdasarkan Pasal 67 Keputusan Presiden Nomor

103 Tahun 2001, BPOM melaksanakan tugas

pemerintahan di bidang pengawasan Obat dan

Makanan sesuai dengan ketentuan peraturan

perundang-undangan yang berlaku. Tugas Balai

Besar/Balai POM (Unit Pelaksana Teknis)

Berdasarkan Pasal 2 Peraturan Kepala

BPOM Nomor 14 Tahun 2014, Unit Pelaksana

Teknis di lingkungan BPOM mempunyai tugas melaksanakan kebijakan dibidang pengawasan obat dan makanan, yang meliputi pengawasan atas produk terapetik, narkotika, psikotropika, zat adiktif, obat tradisional, kosmetik, produk komplemen serta pengawasan atas keamanan pangan dan bahan berbahaya.

Berdasarkan Pasal 69 Keputusan Presiden Nomor 103 Tahun 2001, BPOM memiliki kewenangan :

1. Penyusunan rencana nasional secara makro di bidangnya.

2. Perumusan kebijakan di bidangnya untuk mendukung pembangunan secara makro.

3. Penetapan sistem informasi di bidangnya.

4. Penetapan persyaratan penggunaan bahan tambahan (zat aditif) tertentu untuk makanan dan penetapan pedoman peredaran Obat dan Makanan.

5. Pemberi izin dan pengawasan peredaran Obat serta pengawasan industri farmasi.
6. Penetapan pedoman penggunaan konservasi, pengembangan dan pengawasan tanaman Obat..

Menurut keterangan yang penulis dapatkan dari hasil wawancara melalui telepon langsung pada layanan Lembaga Konsumen Indonesia (021) 7981858 yang berkedudukan di Jalan Pancoran Barat VII/1, Durentiga Jakarta Selatan 12760 Indonesia, hasil wawancara tersebut adalah sebagai berikut :

1. Pertama, cara yang dapat dilakukan untuk mengadu adalah melalui telepon, surat atau datang langsung. Pengaduan melalui telepon dikategorikan menjadi dua yaitu hanya minta informasi atau saran (advice), maka telpon itu cukup dijawab secara lisan pula dan diberikan advice pada saat itu dan selesai

2. Kedua, setelah surat masuk ke YLKI, resepsionis meregister semua surat-surat yang masuk secara keseluruhannya (register I). Selanjutnya surat diberikan kepada Pengurus Harian setidaknya ada tiga yaitu (a) ditindaklanjuti/ tidak ditindaklanjuti (b) bukan sengketa konsumen (c) bukan skala prioritas. Surat di disposisikan ke Bidang Pengaduan Konsumen dilakukan register II Khusus sebagai data pengaduan.

3. Ketiga, setelah surat sampai ke personil yang menangani maka dilakukan seleksi 
administrasi disini berupa kelengkapan

secara administrasi.

4. Pengaduannya untuk ditindaklanjuti. Jika konsumen meminta pengaduannya ditindaklanjuti, maka si penelepon diharuskan mengirim surat pengaduan secara tertulis ke YLKI yang berisi :

a) kronologis kejadian yang dialami sehingga merugikan konsumen

b) wajib mencantumkan identitas dan alamat lengkap konsumen

c) menyertakan barang bukti atau fotocopy dokumen pelengkap lainnya (kwitansi pembelian, kartu garansi, surat perjanjian, dll)

d) Apakah konsumen sudah pernah melakukan komplain ke pelaku usaha. Jika belum pernah, maka konsumen dianjurkan untuk melakukan komplain secara tertulis ke pelaku usaha terlebih dahulu.

e) Cantumkan tuntutan dari pengaduan konsumen tersebut

\section{Proses Administrasi}

Langkah selanjutnya dilakukan setelah proses administasi dan analisis substansi, yaitu korespondensi kepada pelaku usaha dan instansi terkait sehubungan dengan pengaduan konsumen. Pada tahap pertama korespodensi dilakukan bisanya adalah meminta tanggapan dan penjelasan mengenai kebenaran dan pengaduan konsumen tersebut. Di sini YLKI memberikan kesempatan untuk mendengarkan kedua belah pihak yaitu versi konsumen dan versi pelaku usaha. Tidak jarang dengan korespodensi ini kasus dapat diterima masing-masing pihak dengan memberikan jawaban surat secara tertulis ke YLKI yang isinya permintaan maaf kepada konsumen dan sudah dilakukan penyelesaian langsung kepada konsumennya.

Namun demikian, tidak menutup kemungkinan dalam korespondensi ini masingmasing pihak tidak menjawab persoalan dan bersikukuh dengan pendapatnya. Dalam kondisi ini YLKI mengambil inisiatif dan pro aktif untuk menjadi mediator. YLKI membuat surat undangan untuk mediasi kepada para pihak yang sedang bersengketa untuk mencari solusi terbaik.

\section{Proses Mediasi}

Duduk perkara yang sebenarnya tanpa boleh dipotong oleh pihak lain sebelum pihak pertama selesai memberikan penjelasan. Setelah masing-masing menyampaikan masalahnya, maka YLKI memberikan waktu untuk klarifikasi dan koreksi tentang apa yang disampaikan oleh masing-masing pihak.

Setelah permasalahannya diketahui, maka masing-masing pihak berhak menyampaikan opsi atau tuntutan yang diinginkan, sekaligus melakukan negosiasi atas opsi atau tuntutan tersebut untuk mencapai kesepakatan. Apabila telah dicapai kesepakatan, maka isi kesepakatan 
itu dituangkan dalam Berita Acara Kesepakatan.

Tahap akhir dari proses mediasi adalah mengimplementasikan hasil kesepakatan.

Dalam melakukan penyelesaian kasus secara mediasi, ada dua kemungkinan yang bisa terjadi yaitu :

1. terjadinya kesepakatan berarti selesai

2. tidak terjadi kesepakatan alias deadlock, artinya kasus selesai dalam tingkatan litigasi.

Dari pengalaman yang selama ini ditemui bidang pengaduan, mayoritas kasus dapat diselesaikan dengan tercapainya kesepakatan damai. Walau memang ada satu dua yang mengalami deadlock. Namun proses mediasi lebih efektif dan memudahkan untuk segera terselesaikan kasus yang ada.

Jika dilihat dari keseriusan pemerintah dalam hal peredaran makanan yang dikonsumsi masyarakat antara lain yang tertuang dalam Peraturan tentang penggunaan formalin dan bahan kimia tertentu (BKT) dalam produk pangan seperti tercantum dalam Undangundang Nomor 7 Tahun 1996 tentang Pangan serta Undang-undang Nomor 8 Tahun 1999 tentang Perlindungan Konsumen, ada tiga instansi terkait yang berwenang dalam hal pengawasan bahan makanan berbahaya.

Ketiga instansi tersebut adalah Departemen Perindustrian yang bertugas membina industri,Departemen Perdagangan menangani tata niaga dan Badan Pengawasan Obat dan Makanan melakukan pengawasan bahkan penyelidikan langsung sampai ke batas-batas tertentu.Ketiga instansi tersebut diduga kuat tidak berfungsi optimal dalam menindak produsen pengguna formalin, boraks atau sejenisnya dalam makanan. Perlindungan konsumen terhadap produk pangan yang bermasalah, paling efektif dilakukan pemerintah. Idealnya, sistem penyaluran atau distribusi produk pangan sebelum masuk dan ketika beredar di pasaran tak boleh luput dari pengawasan pemerintah. Di negara maju, pemerintahlah yang paling aktif melaksanakan fungsi kontrolnya. Di Indonesia kontrol pemerintah atas tata niaga produk pangan dan bahan pengawet masih lemah. Padahal tata niaga tersebut harus dilakukan secara ketat.

\section{Metode Penelitian}

Metodologi penelitian yang digunakan penulis dalam penulisan hukum ini adalah penelitian hukum yuridis Sosiologis, yaitu penelitian hukum yang menggunakan data sekunder sebagai data awalnya, yang kemudian dilanjutkan dengan data primer atau data lapangan, Meneliti efektivitas suatu UndangUndang dan Penelitian yang ingin mencari hubungan (korelasi) antara berbagai gejala atau variabel sebagai alat pengumpul datanya terdiri dari studi dokumen, pengamatan (observasi), dan wawancara (interview) .

Sifat penelitan yang digunakan bersifat deskriptif analitis dimaksudkan untuk memberikan 
data yang seteliti mungkin tentang permasalahan

yang sedang dikaji dan menggambarkan atau mengemukakan perlindungan hukum terhadap konsumen yang terdapat dalam peraturan perundang-undangan, yang kemudian dianalisis untuk mencari jawaban atas permasalahan yang diajukan.

Sumber data dalam penelitian ini adalah sumber data primer dan sumber data sekunder. Sumber data primer adalah asal data yang diperoleh langsung dari sumbernya, sedangkan sumber data sekunder adalah asal data yang diperoleh tidak langsung dari sumbernya berupa :

\section{Simpulan}

Terdapat beberapa makanan basah yang menjadi sampel penulis dalam penelitian ini mie, bakso, tahu dan ikan asin yang mengandung pengawet berbahaya jenis formalin dimana makanan tersebut tetap awet selama kurang lebih 5 (Lima) hari di ruangan terbuka tidak mengalami perubahan bentuk, rasa dan warna, bau khas formalin, hal ini akan berbeda jika makanan tersebut tidak ditambahkan pengawet dalam satu hari akan basi dan mengalami perubahan bentuk, warna dan rasa serta cenderung berbau asam.

Penggunaan pengawet berbahaya dalam makanan seperti formalin dan boraks adalah melanggar peraturan pemerintah. Karena, dalam jangka panjang pengonsumsinya dapat menderita penyakit kanker dan gangguan ginjal. Kasus penggunaan formalin, boraks dan sejenisnya pada makanan mencerminkan kelemahan koordinasi dari tiga instansi bertanggung jawab menangani peredaran bahan makanan dan minuman. Ketiga instansi tersebut adalah Departemen Perindustrian yang bertugas membina industri, Departemen Perdagangan menangani tata niaga, dan Badan Pengawasan Obat dan Makanan melakukan pengawasan bahkan penyelidikan langsung sampai ke batas-batas tertentu. Ketiga instansi tersebut diduga kuat tidak berfungsi optimal dalam menindak produsen pengguna formalin, boraks atau sejenisnya dalam makanan, sehingga masih ditemukan makanan yang mengandung bahan pengawet berbahaya seperti jenis formalin dan boraks.

\section{Daftar Pustaka}

Fardiaz, Dedi.2009. Buku panduan

Pengolahan pangan yang baik Bagi

Industri Rumah Tangga. Jakarta:Aditya.

Nitisusastro, Mulyadi.2012. Perilaku Konsumen

Dalam Perspektif Kewirausahaan, Cetakan

Kesatu. Alfabeta, CV. Bandung.

Janus, Sidabalok. 2010, Hukum Perlindungan

Konsumen di Indonesia, Bandung : PT.

Citra Aditya Bakti.

Sudaryatmo.1996, Masalah Perlindungan Konsumen di Indonesia, Jakarta: Grafika.

Sofie, Yusuf. 1999, Perlindungan Konsumen dan Instrumen-Instrumen Hukumnya, Bandung: Citra Aditya Bakti. 
44 Perahu, Volume 8 Nomor 1, Maret 2020, Hlm 33-44

Wahyu, Sasongko. 2007, Ketentuan-Ketentuan

Pokok Hukum Perlindungan Konsumen, Bandar Lampung: Universitas Lampung.

\section{Perundang-undangan}

Undang - Undang Nomor 7 tahun 1996 tentang

Pangan

Undang- Undang Nomor 8 tahun 1999 tentang

Perlindungan Konsumen

Undang- Undang Nomor 23 tahun 1992 tentang

Kesehatan

Surat Keputusan Bupati Sintang Nomor:510/156/

KEP-INDAGKOP-C/2015 tentang Pengawasan

Terpadu Bahan Berbahaya Yang Disalahgunakan

Dalam Pangan

Website:

http://suarapemred.co.id/pemerintah-diminta-

intensifkan-pengawasan/22 Agustus 2015

ht t p://www.mediakapuas raya.

com/2015/05/07/2694/tim-terpadu-razia-bahan-

pengawet-di-pasar-junjung-buih/05 Juli 2015

http://www.pom.go.id/new/index.php/view/

lingkup 02 April 2016 
